\title{
Fraud in Universal Coverage: The Usual Suspects (and then Some)
}

\author{
Joan H. Krause
}

\section{INTRODUCTION}

For every clever person who goes to the trouble of creating an incentive scheme, there is an army of people, clever and otherwise, who will inevitably spend even more time trying to beat it.

By all accounts, health care reform is a treacherous undertaking. The effort requires a massive investment of resources-not simply financial, but also the type of political capital that can move constituencies away from entrenched positions of self-interest and toward common ground. Those with the most to gain from upending the current system of health care distribution often have little political voice compared to those with the most to lose. Alignment of the necessary financial, political, and human elements is a rare thing indeed. For any state to navigate these obstacles successfully, as Massachusetts appears to have done, is a significant accomplishment.

Given these concerns, it is understandable that the drafters of the Massachusetts plan did not focus on the system's potential for health care fraud and abuse. Yet it is also unfortunate, because with few exceptions, health care fraud is a crime of opportunity rather than one of desperation. Thus, any reform effort that increases the opportunities to commit fraud, such as increasing the number of players in the health care system and the obligations imposed on them, may well end up losing more money to fraudulent activities. The risk appears to be heightened for reform efforts utilizing the Massachusetts model, which seeks to

\footnotetext{
George Butler Research Professor of Law and Co-Director, Health Law \& Policy Institute, University of Houston Law Center, Houston, Tex.; J.D., Stanford University. I am grateful to Dean Gail Agrawal and Professor Elizabeth Weeks of the University of Kansas School of Law for inviting me to participate in this Symposium. My thanks to Richard Saver, Seth Chandler, Chrisile Hager, David Hyman, Sidney Watson, and all the Symposium participants for sharing their thous:hts on this topic, and to Michael Smith for his research assistance.

1. Steven D. LevitT \& Stephen J. Dubner, Freakonomics: A Rogue EConomist EXPLORES THE HIDDEN SIDE OF EVERYTHING 24-25 (2005).
} 
achieve universal coverage by building on existing third-party payers and government programs rather than instituting a new single payer system.

As we have learned in other contexts, perhaps most importantly from managed care, simply changing the financial structure of the health care system does not necessarily remove the incentive for people to take more from the system than they put in; it simply shifts the fraudulent behavior, often in unanticipated (and less detectable) ways. As Professors Timothy Jost and Sharon Davies have observed, "the fundamental human traits addressed by the fraud and abuse laws-greed and venality - do not disappear and are not tamed simply because arrangements for the financing and delivery of health care are changed. These traits simply manifest themselves in new forms or in new variations of old forms."2 This aspect of human nature appears depressingly resilient, even in the face of changes made with the most admirable of intentions. Rather than determining whether people will cheat under a system such as the Massachusetts plan, then, the question is how they will cheat-and whether the system is capable of detecting fraud in its new guises.

The goal of this commentary is to highlight the ways in which the Massachusetts model of health care reform may have the unintended effect of permitting health care fraud to flourish, both by current market players and by new parties who will be brought into the system. Given the many public references to the bipartisan genesis of the Massachusetts plan, it is worth noting that the prevention of health care fraud and abuse is a bipartisan goal as well. ${ }^{3}$ Ultimately, then, health care reform and fraud prevention need not be viewed as inherently incompatible.

\section{FRAud IN THE HEALTH CARE SyStem}

In order to determine the effect of a multi-payer universal coverage system on health care fraud, it is important to review what we currently know about the problem. Fraud and abuse are frustrating constants in the United States health care system. The first audit of Medicare fee-forservice payments found that more than $\$ 23$ billion had been paid out improperly in fiscal year 1996 alone-an error rate of more than $13 \%{ }^{4}$

2. Sharon L. Davies \& Timothy Stoltzfus Jost, Managed Care: Placebo or Wonder Drug for Health Care Fraud and Abuse?, 31 GA. L. REv. 373, 373-74 (1997).

3. Indeed, the federal government's Fraud and Abuse Control Program was one of the bipartisan compromises generated by the failed Clinton health care reform effort. See Health Insurance Portability and Accountability Act of 1996, Pub. L. No. 104-191, § 201, 110 Stat. 1936, 1992 (1996) (establishing a "Fraud and Abuse Control Program").

4. See, e.g., Department of Health \& Human Services OfFice of The Inspector General, No. A-17-01-02002, IMPROPER FISCAL YEAR 2001 MEDICARE FEE-FOR-SERVICE 
Although the numbers have improved each year, auditors still estimate that improper Medicare payments totaling $\$ 10.8$ billion were made in $2006 .^{5}$ Consistent with this focus, recent years have seen more funds appropriated to the federal agencies with jurisdiction over health care fraud, particularly the Department of Justice (DOJ) and the Department of Health \& Human Services (HHS) Office of the Inspector General (OIG). These investments clearly have paid off: the federal government won or negotiated approximately $\$ 1.47$ billion in health care judgments and settlements in fiscal year $2005 .^{6}$ Although the extent to which those numbers can be extrapolated to the private sector remains uncertain, it is clear that the overall magnitude of the diverted funds is large, and this amount has proven resistant to virtually all eradication efforts. While it may no longer be fashionable to insist that reducing health care fraud is a quick and easy way to fund health care reform, the amount of money at stake remains substantial enough to jeopardize many innovative reform efforts.

\section{A. Fraud, Abuse, and Waste}

Not all health care "fraud" is equal-indeed, not every improperly paid dollar is necessarily a dollar lost to fraud at all. ${ }^{7}$ One of the reasons it is so difficult to either estimate or to eradicate health care fraud is that the phrase encompasses several types of disfavored financial activities, ranging from intentional efforts to misappropriate government money to behaviors that are merely profligate with regard to the funds set aside for health care. Although the terms are often used interchangeably (and may be equally subject to many of the anti-fraud laws), it is important to distinguish among the concepts of fraud, abuse, and waste. ${ }^{8}$

PAYMENTS 1 (2002), available at http://oig.hhs.gov/oas/reports/cms/a0102002.pdf (reviewing 1996 data).

5. Centers for Medicare \& Medicaid Services, Improper Medicare fFS Payments LONG REPORT (WEB VERSION) FOR NOVEMBER 2006 (2006), https://www4.cms.hhs.gov/apps/er report/preview_er_report.asp?from=public\&which=long\&reportID=5\&tab=2.

6. DEPARTMENT OF HEALTH AND HUMAN SERVICES AND DEPARTMENT OF JUSTICE, HEALTH

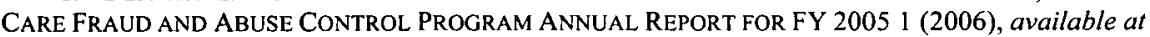
http://www.usdoj.gov/dag/pubdoc/hcfacreport2005.pdf.

7. See, e.g., David A. Hyman, HIPAA and Health Care Fraud: An Empirical Perspective, 22 CATO J. 151, 162 (2002) (arguing that OIG and Centers for Medicare and Medicaid Studies audits are not designed to measure true fraud).

8. For an overview of these concepts and their effects on the fraud and abuse debate, see generally Jerry L. Mashaw \& Theodore R. Marmor, Conceptualizing, Estimating, and Reforming Fraud, Waste, and Abuse in Healthcare Spending, 11 YALE J. ON REG. 455 (1994). 
True fraud involves actions taken with the intent to deceive. In health care, this will most often involve a willful misrepresentation of the relevant facts on which payers rely in making reimbursement decisions, what Professor James Blumstein has called "raw fraud." An example would be a physician who bills for services never performed, or for patients never treated. ${ }^{10}$ Abusive behavior lacks the element of intent, instead involving actions such as "gaming the system" by creatively reading reimbursement rules to permit practices that violate the spirit, if not actually the letter, of the law. "Abusive practices often straddle the line between expenditures of medical resources made primarily in selfinterest and those made pursuant to good faith belief in medical necessity, such as when a physician insists on performing two separate procedures when both could have been performed more economically at the same time. ${ }^{12}$ Wasteful practices, by contrast, are not actively fraudulent and do not seek to exploit uncertainty in regulatory rules. Rather, the concept is most often used to describe activities that are not cost-effective, yet persist because of other incentives in the current health care system. ${ }^{13}$ An example might be so-called "defensive medicine" practices, where unnecessary tests and procedures are ordered out of fear that failure to do so might lead to a malpractice action, or the persistence

9. James F. Blumstein, What Precisely is "Fraud" in the Health Care Industry?, WaLl ST. J., Dec. 8, 1997, at A25. See also Mashaw \& Marmor, supra note 8, at 463 ("Classic fraud involves the misrepresentation of relevant facts combined with the detrimental reliance on that misrepresentation by another party to the transaction."); GENERAL ACCOUNTING OFFICE, GAO/HRD-92-69, HEALTH INSURANCE: VULNERABLE PAYERS LOSE BILlIONS TO FRAUD AND ABUSE 2 (1992) (noting "fraud generally involves a willful act") [hereinafter GAO, VULNERABLE PAYERS].

10. See, e.g., United States v. Sidhu, 130 F.3d 644, 647 (1997) (alleging that psychiatrist submitted bills for services not performed, including a bill for psychotherapy services for a patient who was already dead).

11. See Mashaw \& Marmor, supra note 8, at 463 ("[A]buse describe[s] instances of profligate spending on medical care that is at the margin of fraudulent practice, in which the conduct in question is permitted by the existing arrangements for medical care provision and financing."); GAO, VULNERABLE PAYERS, supra note 9, at 2 ("[A]buse typically involves actions that are inconsistent with acceptable business and medical practices.").

12. See, e.g., United States v. Laughlin, 26 F.3d 1523, 1530-31 (1994) (involving a physician who was convicted of Medicaid fraud, and whose sentence was increased because of risks posed to a patient when he performed a tubal ligation four weeks after delivering the patient's baby by csection rather than performing both procedures at one time. In his defense, the physician argued that he did so to allow the patient to heal from the earlier surgery). As Mashaw and Marmor note, "[c]ommon to all these cases is some plausible medical explanation for the procedure. Abuse lies in the motivation imputed to the provider, in the suspicion that costs were increased for purposes related, at best, only tangentially to producing a better medical result." Mashaw \& Marmor, supra note 8 , at 464 .

13. See Mashaw \& Marmor, supra note 8 , at $464-66$ (describing how cost-ineffective practices are often justified by some medical rationalization). 
of payer-specific billing systems when a universal billing form would be less expensive. ${ }^{14}$

While fraudulent, abusive, and wasteful practices all cause monetary loss, the appropriate legal response to each activity may be different. At one end of the spectrum, there is widespread consensus that intentional fraudulent activity should be addressed through criminal statutes imposing fines and imprisonment, powerful civil sanctions requiring hefty statutory penalties and disgorgement of multiple times the monetary gain, or exclusion from federal health care programs. ${ }^{15}$ At the other end of the spectrum, wasteful practices are often viewed as demanding a systemic response-be that response something as sweeping as medical malpractice reform, or as specific as the development of clinical practice guidelines to advise busy health care professionals on the best way to treat a particular condition. ${ }^{16}$

Abusive activities, however, are another matter. In large part, this stems from the fact that abusive acts can be characterized in two starkly different ways. From one vantage point, abusive acts are nearly as bad as actively fraudulent ones-either due to the monetary losses caused or to the belief that one who engages in such activities clearly has demonstrated a disregard for the ethical rules that should govern behavior in the health care industry. ${ }^{17}$ The proper response to abusive acts, from this perspective, is nearly identical to that involving fraud. Thus, many of the powerful criminal and civil statutes applicable to health care fraud can be satisfied by proof of mental states that fall short of traditional notions of "intent." For example, the civil False Claims Act defines the "knowing" submission of false claims to include not only

14. Id. at 467.

15. See, e.g., 18 U.S.C. $\$ 1347$ (2000) (defining crime of "Health care fraud" and imposing up to life imprisonment if a violation results in death); 31 U.S.C. $\$ 3729(2000)$ (setting forth provisions of the civil False Claims Act (FCA), which imposes statutory penalty of $\$ 5000$ to $\$ 10,000$ per violation, plus treble damages); 28 C.F.R. $\S 85.3(a)(9)$ (increasing FCA statutory penalty by 10 percent, to a range between $\$ 5500$ and $\$ 11,000$ ); 42 U.S.C. $\$ 1320 \mathrm{a}-7$ a (2000) (listing grounds for mandatory exclusion).

16. See, e.g., TEX. CIV. PRAC. \& REM. CODE ANN. $\$ 74$ (Vernon 2005) (amending medical malpractice statute in order to reduce the amount of damages awarded to claimants); National Guideline Clearinghouse, www.guideline.gov (last visited Jan. 26, 2007) (providing public access to evidence-based clinical practice guidelines, maintained by the HHS Agency for Healthcare Research and Quality).

17. See, e.g., Timothy Stoltzfus Jost \& Sharon L. Davies, The Empire Strikes Back: A Critique of the Backlash Against Fraud and Abuse Enforcement, 51 ALA. L. REV. 239, 239 (1999) (arguing in favor of widespread agreement "that Medicare and Medicaid fraud and abuse is morally wrong and fiscally harmful"); James Sheehan, Bio-Tech Fraud: Reality or Fantasy?, 2 Hous. J. HEALTH L. \& POL'Y 11, 18 (2002) (arguing that fraud laws serve to "prohibit a breach of good faith and fair dealing as understood in the community involving a deception or breach of trust"). 
actual knowledge but also deliberate ignorance or deliberate disregard of truth or falsity, with no proof of specific intent required. ${ }^{18}$ With the same penalties applicable to both fraudulent and abusive acts, there appears to be little incentive-coupled with a strong moral disinclination-to bother with the distinction at all.

Viewed from an equally compelling perspective, however, abusive acts are not simply inchoate frauds. Instead, such activities may involve a "gray area that requires the exercise of judgment" on the part of the provider. ${ }^{19}$ As I have argued elsewhere, the way to achieve a long-term reduction of undesirable activities in such gray areas is not higher penalties but regulatory clarity - the practice of revising incomplete, conflicting, and confusing regulatory guidance to make clear exactly what is expected of the provider in the first place. ${ }^{20}$ The failure to separate fraudulent from abusive activities results not only in unfairness to individual defendants, but more insidiously obscures the need for systemic changes designed to address these loopholes-thereby perpetuating an escalating cycle of abusive practices. While a health care reform plan that focused on fraud and abuse might well make headway in resolving these problems, several aspects of a multi-payer universal health care system may instead have the effect of exacerbating all three types of concerns, as well as the confusion among them.

\section{B. The "Usual Suspects" in Health Care Fraud}

Although the permutations of health care fraud and abuse may appear to be endless, the activities in fact involve a relatively limited population of actors-whom I call the "usual suspects." To modify a taxonomy used by Professors Timothy Jost and Sharon Davies in the managed care context, health care fraud involves relationships between and among four basic actors: (1) the patients (or consumers) who receive medical services that are paid for, at least in part, by some form of insurance; (2) the purchasers (also known as sponsors or payers) who

18. 31 U.S.C. $\$ 3729$ (b) (2006). A similar interpretation has been applied under the criminal false claims provisions. United States v. Nazon, 940 F.2d 255, 259 (7th Cir. 1991) (explaining that a "conscious avoidance" instruction can be used in a criminal false claims case when there is evidence of the defendant's deliberate ignorance). Similarly, the Stark self-referral prohibition has no intent requirement at all. 42 U.S.C. $\$ 1395 \mathrm{nn}(2006)$.

19. Blumstein, supra note 9 , at A25.

20. See, e.g., Joan H. Krause, A Conceptual Model of Health Care Fraud Enforcement, 12 J.L. \& POL'Y 55, 130-47 (2003) (identifying problem and calling for efforts to achieve regulatory clarity); Joan H. Krause, Health Care Providers and the Public Fisc: Paradigms of Government Harm Under the Civil False Claims Act, 36 GA. L. REV. 121, 206-16 (2001) (suggesting ways to increase the legitimacy of anti-fraud efforts). 
pay for health care, a group composed primarily of private employers and the state and federal government entities that sponsor public health insurance programs such as Medicare and Medicaid; (3) the providers, both institutional and individual, that render medical services; and (4) the intermediaries that administer health care benefits, process insurance claims, and sometimes bear financial risk (as in the case of a traditional indemnity policy sold by a private insurer). ${ }^{21}$ Without being unduly cynical, there is potential for fraud whenever two or more of these parties interact.

How does such fraud occur? Patients, for example, may defraud purchasers and intermediaries by falsely seeking to become entitled to benefits, or by requesting coverage of services they do not needschemes that can be as diverse as falsifying insurance applications, participating in fake automobile accidents, or falsely claiming workrelated disabilities. ${ }^{22}$ Similarly, a purchaser may misrepresent a benefit plan to potential enrollees, fail to deliver the benefits promised, or unlawfully seek to discriminate in the benefits offered to individuals on the basis of considerations such as health status. ${ }^{23}$ In perhaps the most commonly cited form of fraud, a health care provider may falsify bills in order to obtain payment for services that were not performed, or for a more expensive type of service than was rendered. ${ }^{24}$ Part of the impetus for the Massachusetts reform effort came from concerns raised by a similarly abusive provider practice: the failure of hospitals in the state to aggressively screen uninsured patients for Medicaid eligibility, chiefly because reimbursement through the state's Free Care Pool was greater than that available through the Mass Health program. ${ }^{25}$ Finally, the

21. See Davies \& Jost, supra note 2, at 380-83 (stating, "[c]onceptually, health care transactions in the United States involve four parties: consumers, providers, purchasers, and intermediaries") (citing Jonathan P. Weiner and Gregory de Lissovoy, Razing a Tower of Babel: $A$ Taxonomy for Managed Care and Health Insurance Plans, 18 J. HEALTH POL. POL'Y \& L. 75, 80-81 (1993)).

22. See, e.g., United States v. Lucien, 347 F.3d 45, 50-51 (2d Cir. 2003) (applying 18 U.S.C. § 1347 to individuals who posed as passengers injured in staged automobile accidents for the purpose of defrauding the New York no-fault automobile insurance program); Davies \& Jost, supra note 2, at 383-84 (stating consumers may defraud purchasers "when they feign illness, disability, or financial dependency").

23. See, e.g., 29 U.S.C. $\S 1132(\mathrm{a})(1)(\mathrm{B})(2006)$ (permitting employee benefit plan participant or beneficiary to bring suit under ERISA for benefits due); 29 U.S.C. $\$ 1182(a)(1)$ (2006) (prohibiting group health plans from discriminating against individuals on the basis of health status under HIPAA); Davies \& Jost, supra note 2, at 384 (discussing the liability of purchasers who misrepresent their benefit plans to consumers).

24. See, e.g., United States v. Sidhu, 130 F.3d 644, 647-48 (5th Cir. 1997) (describing various forms of billing fraud); Davies \& Jost, supra note 2, at 384 (discussing how providers can submit claims for items or services not provided).

25. See State Watch: Massachusetts Attorney General Investigates Overbilling of State 
current health care system offers ample opportunity for fraudulent behavior by intermediaries, including misrepresenting insurance products to purchasers and patients, failing to deliver promised services to patients, and failing to process claims promptly and accurately. ${ }^{26}$

As we have seen in the context of managed care, while health care reform efforts may change the alignment of incentives among these parties, they rarely have the effect of completely eliminating the temptation (let alone the ability) to commit fraud. Rather, as Professor Pamela Bucy has noted, "the way we pay people affects the way they cheat." 27 Thus, a provider who is reimbursed under a fee-for-service system has a financial incentive to perform additional services for a patient (or at least to submit bills for such services), while a provider paid under capitation has an incentive to perform fewer services. Under either approach, there is both motive and opportunity for the provider to game the system. As the authors of the popular book Freakonomics note, "Cheating may or may not be human nature, but it is certainly a prominent feature in just about every human endeavor. Cheating is a primordial economic act: getting more for less." ${ }^{28}$ The question is, in what ways do these temptations play out under a scheme of multi-payer universal coverage?

\section{Fraud Detection and Prevention}

Before turning to the specifics of the Massachusetts reform plan, there is one more issue to be addressed: given the myriad motivations to engage in fraudulent and abusive health care behaviors, what strategies are commonly used to prevent such acts from occurring? As I said at the outset, health care fraud is primarily a crime of opportunity. There are two basic ways of reducing its occurrence: (1) decrease the opportunities for such fraud to occur, such as by closing loopholes and clarifying regulatory gray areas; or (2) increase the level of deterrence, such as by imposing higher penalties or increasing program oversight, so that an actor who discovers an opportunity to commit fraud will calculate that it

Uncompensated Care Pool After Audit Finds Excessive Charges, KAISER DAILY HEALTH POL'Y REP., Feb. 14, 2006, http://www.kaisernetwork.org/daily_reports/rep_index.cfm?hint=3\&DR $\mathrm{ID}=35409$ [hereinafter State Watch] (alleging that hospitals "inflated charges to the pool to compensate for shortfalls in Medicaid reimbursements").

26. See, e.g., Davies \& Jost, supra note 2, at 386-87 (describing ways in which an intermediary can limit access to services and engage in false marketing activities in a managed care environment).

27. Pamela H. Bucy, Health Care Reform and Fraud by Health Care Providers, 38 VILL. L. REV. 1003, 1049 (1993).

28. LEVITT \& DUBNER, supra note 1 , at 25. 
is not in his or her best interest to proceed. While a full discussion of this issue is beyond the scope of this Commentary, ${ }^{29}$ it is worth noting the obvious corollary: changes in the health care market that have the effect of creating additional loopholes or confusion, while decreasing or holding steady deterrent strategies, can be predicted to result in increased fraudulent and abusive activities. The tensions have been described by Professor Fran Miller, who aptly observed that "[i]f we are to embrace the principle of universal health insurance coverage, yet avoid investing massive new resources in the health sector, reform must be structured to minimize the potential for excessive private gain at the expense of costeffective medical care." 30

How do market-based universal coverage proposals, and the Massachusetts plan in particular, fare under these criteria? For obvious reasons, multi-payer systems are significantly more administratively complex than single payer models. This complexity "renders fraud and abuse easier for those willing to engage in it, and its decentralization adds to the monitoring problems of federal, state and private officials.",31 As the General Accounting Office has noted, "[t]he health care insurance system is a myriad of health care payers and methods of reimbursing providers. This complex system itself becomes an impediment to detecting fraud and abuse." 32 For this reason, a reform effort that builds on the current multi-payer system is unlikely to achieve fraud control through the strategy of regulatory clarification, and by necessity will likely rely on the development of additional deterrence mechanisms. Two examples illustrate this phenomenon: the new Medicare prescription drug benefit, and the proposals for national health care reform debated in the early 1990's.

29. For a good introduction to these issues, including an economic analysis of deterrence in health care fraud cases, see Jost \& Davies, supra note 17, at 265-313, and sources cited therein.

30. Frances H. Miller, Doctors' Conflicts of Interest (\& Altruism) in the United States and Great Britain, 27 IND. L. REV. 687, 697 (1994) (reviewing MARC A. RODWIN, MEDICINE, MONEY \& MORALS: PHYSICIANS' CONFLICTS OF INTEREST (1993)).

31. Mashaw \& Marmor, supra note 8, at 488. But see DAVID A. HYMAN, MEDICARE MEETS MEPHISTOPHELES 25 (2006) ("Medicare's proponents routinely brag about its low administrative overhead. Of course, the figure is artificially low because Medicare has no marketing expenses, and it uses employers, the Internal Revenue Service, and the Social Security Administration to collect and process its premiums.").

32. GAO, VULNERABLE PAYERS, supra note 9, at 13. See also Bucy, supra note 27, at 102223 (arguing that health care reform efforts should include uniform billing and payment provisions in order to reduce fraud); Mashaw \& Marmor, supra note 8, at 483 (noting that "[m]anaged competition has significantly less power to reduce administrative costs than does a single-payer plan."). 
The Medicare Prescription Drug, Improvement, and Modernization Act of $2003^{33}$ created a voluntary prescription drug benefit for Medicare beneficiaries, which went into effect in January 2006. ${ }^{34}$ The new Medicare Prescription Drug Benefit relies on a network of regional Prescription Drug Plans (PDPs) that compete for patients on the basis of price, drug selection, and expanded Medicare managed care offerings that include drug coverage (Medicare Advantage). Although the program has required the creation of a new administrative structure within the Centers for Medicare and Medicaid Services (CMS), ${ }^{35}$ the program relies on existing players in the health care market for the delivery of these new services, including pharmaceutical benefit managers, managed care organizations, pharmacies, and pharmaceutical company patient assistance programs. Not surprisingly, such an administratively complex system clearly provides opportunities for fraud; indeed the program may have set a record in this regard, with the first reports of fraud in the transitional discount card program coming almost before the program went into effect. ${ }^{36}$ While the speed with which the first fraudulent schemes arose may have caught some offguard, the potential for fraud in the new program was well-recognized. Both the law and regulations include numerous provisions targeting financial misbehavior (particularly in regard to assistance for financially disadvantaged patients), and Part D oversight is expected to comprise a major element of the government's regulatory and enforcement agenda in the coming years. ${ }^{37}$

33. Pub. L. No. 108-173, 117 Stat. 2066 (2003).

34. Id. at 2072-73.

35. For access to the CMS documents and data on Part D, see CMS, Prescription Drug Coverage-General Information, http://www.cms.hhs.gov/PrescriptionDrugCovGenIn/ (last visited Mar. 2, 2007).

36. CMS, FACT SHEET: MEdiCARE BENEFICIARIES WARNED AbOUT DRUG CARD SCAMS, Apr. 22, 2004, available at http://www.cms.hhs.gov/apps/media/press/fact_sheet.asp?Counter=1018 (describing attempts "to gain personal information from beneficiaries with the intent to scam the beneficiaries" in several states).

37. See, e.g., 42 U.S.C.A. § 1395w-3a(d)(4) (Supp. 2006) (creating civil penalty for misrepresentation of pricing information by manufacturer); 42 C.F.R. $\S 423.752$ (Supp. 2006) (setting forth grounds for imposition of intermediate sanctions and civil monetary penalties for Part D sponsors); Publication of OIG Special Advisory Bulletin on Patient Assistance Programs for Medicare Part D Enrollees, 70 Fed. Reg. 70,623 (Nov. 7, 2005), (setting forth OlG guidance related to drug assistance programs); CMS, PRESCRIPTION DRUG BENEFIT MANUAL: CHAPTER 9 - PART D Program to CONTROL FRAUd, WASTE AND ABUSE, available at http://www.cms.hhs.gov/ PrescriptionDrugCovContra/Downloads/PDBManual_Chapter9_FWA.pdf (providing "both interpretive rules and guidelines for Part D plan sponsors on how to implement the regulatory requirements"); Robert N. Rabecs, Health Care Fraud Under the New Medicare Part D Prescription Drug Program, 96 J. CRIM. L. \& CRIMINOLOGY 727 (2006) (discussing potential fraud and abuse under Part D health plans). 
Congress demonstrated similar awareness of the fraud and abuse potential inherent in multi-payer reform schemes during the Clinton health plan debate in the mid-1990s. The Health Security Act was a reform proposal of almost mind-numbing administrative complexity, with a convoluted combination of public and private mechanisms used to achieve universal coverage. ${ }^{38}$ To counteract the enormous potential for fraud in such an administratively complex system, the Act (as well as many of the competing market-based proposals) incorporated a variety of new provisions targeted at reducing fraud and abuse, such as extending existing Medicare/Medicaid anti-fraud provisions to cover all payers, increasing the number and amount of civil monetary penalties, and creating a new class of federal health care crimes applicable to fraud against any public or private health care plan. ${ }^{39}$ Indeed, it is fascinating to note that while the core coverage provisions of the Act quickly fell by the wayside, many of the anti-fraud provisions became law with the enactment of HIPAA ${ }^{40}$ - suggesting how easily a single-minded focus on health care fraud can obscure broader policy goals. By contrast, the single payer reform proposals would have controlled fraud and abuse chiefly by extending existing Medicare/Medicaid anti-fraud provisions to the states, with few new protections needed. ${ }^{41}$ These examples demonstrate that federal lawmakers have long been cognizant of the fact that market-based health care reform efforts likely will require enhanced deterrence in order to counteract new incentives to commit fraud.

\section{FRAUD IN UNIVERSAL COVERAGE: THE MASSACHUSETTS EXAMPLE}

Given this history, how does the Massachusetts reform plan fare? In short, the legislation creates many new administrative entities, gives both new and old "suspects" additional motivations and opportunities to

38. H.R. 3600, 103d Cong. (1994).

39. See id. $\S \S 5201-5441$ (proposing changes to fraud and abuse provisions); Matthew $P$. Harrington, Health Care Crimes: Avoiding Overenforcement, 26 RUTGERS L.J. 111, 126-42 (1994) (describing fraud and abuse provisions in the various reform proposals). According to one Clinton plan critic, "the disturbing thing about the proposal is its reliance on a number of ill-advised and, in some cases, draconian criminal provisions, which, taken together, constitute an unprecedented interference with the states' traditional role in law enforcement." Harrington, supra, at 145.

40. See, e.g., 42 U.S.C. $\S \S 1320 \mathrm{a}-7$ (a) (2000) (expanded exclusion authority); id. $\S \S 1320 \mathrm{a}-7 \mathrm{a}$ (expanded civil monetary penalties provisions); id. $\$ \S 1320 \mathrm{a}-7 \mathrm{~b}(\mathrm{~b})$ (extending Anti-Kickback statute to all federal health care programs); 18 U.S.C. $\$ \S 24,669,1035,1347,1518$ (2000) (defining new federal health care fraud crimes).

41. See Harrington, supra note 39 , at $144-45$ (noting the "single-payer proposal does not really appear to create new enforcement mechanisms; it merely expands the scope of those currently in piace"). 
commit fraud, and includes relatively few penalties that could be considered serious deterrents to engaging in undesirable behaviors. These problems may not doom the Massachusetts plan, chiefly because the state already has very strong anti-fraud laws in place. Nevertheless, they raise serious questions about whether similar multi-payer reform efforts can succeed in other states with less favorable anti-fraud environments.

\section{A. Complexity}

By relying on a combination of public and private mechanisms to increase health care coverage, like the Clinton proposal, Massachusetts has created a highly complex and bureaucratic system. Although far from a scientific survey, I count at least eight new governmental bodies created by the law, including the Health Care Quality and Cost Council, the Health Disparities Board, and the all-important Commonwealth Health Insurance Connector Authority. ${ }^{42}$ Admittedly, administrative complexity does not translate directly into fraud and abuse. But at the very least, the number of new entities raises the possibility of duplication and waste, especially in light of concerns regarding the future solvency of the program in a state with historically high health care costs-and little emphasis in the reform plan itself on cost and efficiency. ${ }^{43}$

\section{B. New Suspects and New Motivations for the "Usual Suspects"}

More important than the sheer number of state entities involved in the new program is the complexity of the provisions they are asked to administer. Because of the way the program is structured, many actorsboth the "usual suspects" and newer parties-will have motive and

42. See, e.g., An Act Providing Access to Affordable, Quality, Accountable Health Care, ch. $58, \S \S 3,5,6,8,11,30,45,101,2006$ Mass. Acts (forthcoming), available at http://www.mass.gov/ legis/laws/seslaw06/s1060058.htm [hereinafter An Act Providing Health Care Access]. According to one attorney who was involved in the drafting process, the legislation affected a total of nineteen different state agencies. Christie Hager, Health Reform in Massachusetts: A Social Compact and a Bold Experiment, Remarks at the Kansas Law Review Annual Symposium: The Massachusetts Plan and the Future of Universal Coverage (Nov. 10, 2006).

43. In the words of one commentator: "To be blunt, Massachusetts is a very high-cost state for health care, with a concentrated market of relatively inefficient providers already swimming in a sea of dysfunctional public subsidies and crippling overregulation." Tom Miller, Massachusetts: More Mirage Than Miracle, 2006 HeAlTH AFFS.: Web EXClusives w450, w452. See also Nancy C. Turnbull, The Massachusetts Model: An Artful Balance, 2006 HEALTH AFFS.: WEB EXCLUSIVES w453, w455 ("Managing the growth of health care costs is not a major focus of the new law. In fact, some key provisions will increase health spending."). 
opportunity to engage in a variety of fraudulent and abusive activities. This is chiefly due to the new obligations created under the law and the relatively weak enforcement mechanisms in place to back them up.

The chief obligation placed on patients under the reform plan is the so-called individual mandate, a requirement that as of July 1, 2007, all Massachusetts residents over the age of 18 obtain health insurance coverage as long as such coverage is deemed to be "affordable" for them. ${ }^{44}$ A wide variety of coverage options will satisfy the mandate, including employer-sponsored health insurance, Medicare and Medicaid coverage, or an individual policy purchased through the Commonwealth Health Insurance Connector (Connector) (including those subsidized by the Commonwealth Care Health Insurance Program (CCHIP)). Although the drafters of the legislation hoped to increase the availability of employer-sponsored health insurance, it seems clear that the law will also have the effect of increasing the numbers of those purchasing policies directly through the Connector-mediated individual market. That might change, however, if the affordability loophole grows large enough to swallow the rule: if many people ultimately cannot obtain affordable care through the Connector, as some critics have predicted, this may derail the entire health reform plan and result in waste on a massive scale. ${ }^{45}$ Moreover, the CCHIP program, designed to provide premium assistance subsidies to state residents with incomes below $300 \%$ of the federal poverty level, may invite abuse by individuals who seek to obtain subsidies to which they should not be entitled. ${ }^{46}$

The legislation also imposes significant obligations on purchasers, most notably employers. Under the law's so-called "pay-or-play" mandate, every employer with more than ten full-time employees that does not make a "fair and reasonable premium contribution" to a group health plan must pay an annual "fair share employer contribution" not to exceed $\$ 295$ per employee (designed to offset a portion of the costs incurred by the state for free care for workers whose employers do not offer insurance). ${ }^{47}$ This structure may provide an incentive for

44. An Act Providing Health Care Access, supra note $42, \S 12$.

45. See Susan Dorr Goold \& Nancy M. Baum, Define "Affordable", Hastings CTR. REP., Sept.-Oct. 2006, at 22, 22-24 (addressing affordability problems); Marcia Angell, Healthcare Plan Needs Dose of Common Sense, BoSton GloBE, Apr. 17, 2006, at A15 (estimating that individual coverage in Massachusetts costs $\$ 7,200$ a year).

46. See An Act Providing Health Care Access, supra note $42, \S 45$ (stating the requirements to be eligible for participation in the program).

47. Id. § 47; 114.5 MASS. CODE REGS. 16.03 (2006) (defining an employer's "fair and reasonable contribution" as either $25 \%$ of employees enrolled in the employer-sponsored group health plan or the employer's offer to pay at least $33 \%$ of the premium cost). A small-group employer may choose to meet its obligations by entering into an agreement with the Connector, 
employers not only to shirk their respective premium responsibilities, but also to calculate the number of their full-time equivalent employees in such a way as to fall outside the mandate. Other new employer obligations include the payment of a "free rider surcharge" if employees who are not offered health insurance use state-funded free care services, ${ }^{48}$ and the mandatory offering of a section 125 cafeteria plan that permits employees to purchase various health-related benefits on a pretax basis. ${ }^{49}$

Although most of the statutory mandates fall on individuals and employers, health care providers may wind up bearing the brunt of the financial reallocation. One of the oft-mentioned reasons for the feasibility of the Massachusetts approach was the state's well-funded uncompensated care pool - a remnant of a prior failed health reform effort that permitted hospitals to bill the state for the costs of treating low-income patients rather than having to offset those costs by raising prices to other payers. ${ }^{50}$ That pool, estimated at over $\$ 500$ million in $2005,{ }^{51}$ provided ready-made funding for the new reform effort (most notably the CCHIP subsidies). By reallocating these funds for insurance premium subsidies rather than spending them on direct care, Massachusetts is basically gambling that the population of people who previously received free services will be able to obtain subsidized insurance coverage. If this strategy works, the costs of care for this population should be covered by the new insurance, and there should be little need for a free care pool.

If the gambit fails, however, both patients and health care providers will be caught in the middle. If the newly subsidized insurance does not in fact cover the costs of care-either because individuals are not able to take advantage of such subsidies or because the subsidized policies do not provide adequate coverage of services-patients will still present themselves at hospitals in need of care, but that care will no longer be fully compensated under what remains of the pool. These pressures will be heightened starting in 2008, when providers will be expected to comply with performance markers in order to be eligible for increased

under which the employer must carefully coordinate premium payments with the Connector (and CCHIP, if applicable to individual employees). An Act Providing Health Care Access, supra note $42, \S 101$.

48. See An Act Providing Health Care Access, supra note 42, § 44 (addressing free rider surcharge).

49. See id. $\S 48$ (requiring cafeteria plans).

50. Jonathan Gruber, The Massachusetts Health Care Revolution: A Local Start for Universal Access, HASTINGS CTR. REP., Sept.-Oct. 2006, at 14, 16 (describing the funding pool).

51. Id. 
Medicaid reimbursement. ${ }^{52}$ In short, providers are likely to have strong motivation to find creative ways to make up the lost funding -or, in the alternative, to turn patients away, a result clearly not desired by the legislation.

Nor are intermediaries immune from the obligations imposed by the new law. The chief concerns are likely to be the truthfulness and accuracy of the health insurance policies offered through the Connector, and compliance with the guaranteed issue and other requirements in the (soon-to-be-merged) small business and individual markets. ${ }^{53}$ While these may be common concerns in the insurance industry overall, the creation of the Connector will introduce novel pressures into the marketplace. The Connector is designed to function as a clearinghouse through which individuals can gain access to insurance policies that meet certain minimal criteria. ${ }^{54}$ Because a new state entity is now interposed between the insurer and the population of potential enrollees, there may be incentives for insurers to bribe or otherwise try to influence the Connector Authority decisionmakers to assure sure that their products are included. $^{55}$ More broadly, intermediary behavior may raise moral and ethical concerns: will intermediaries take up the challenge and make low-cost policies of value available to both individuals and employers, or will the goal of affordable universal coverage remain illusory?

Finally, the Massachusetts plan rests substantial discretion with the individuals who serve on the Connector Authority and the other public bodies created by the legislation. ${ }^{56}$ As noted above, the individuals who control the Connector may have both motive and opportunity to engage in bribes or other forms of graft in connection with favorable treatment

52. An Act Providing Health Care Access, supra note 42, $\S 25$. The legislation created a Health Safety Net Trust Fund, but it is clear that this fund is to be used only as a last resort; hospitals and community health centers are directed to aggressively screen patients for potential eligibility under other state programs, including Medicaid and CCHIP. Id. § 30 . Therefore, providers who do not receive increased Medicaid payment rates will no longer have the ability to selectively bill the state for the difference. See State Watch, supra note 25 (noting hospital officials inflated charges to the pool to compensate for shortfalls in Medicaid reimbursements).

53. See MASS. GEN. LAWS ANN. ch. 176J (West 2006) (outlining small group health insurance).

54. See id. ch. 176Q, $\S 5$ (West 2006) (limiting plans that may be offered through Connector).

55. Cf. Bucy, supra note 27 , at 1039-40 (describing how managed competition models raise "the potential for large-scale corruption, a type of criminality not seen much in the heretofore privately operated health care system"). This may be analogous to payments made to induce an insurer to include a particular drug in a restricted formulary. See OlG Compliance Program Guidance for Pharmaceutical Manufacturers, 68 Fed. Reg. 23,731-01 (May 5, 2003) (warning that "[l]ump sum payments for inclusion in a formulary ... are problematic and should be carefully scrutinized").

56. See supra note 42 and accompanying text (noting the number of state agencies affected by the legislation). 
of insurance products. More globally, these individuals have the potential to derail the entire reform effort over time by failing to administer the program in a way that restrains costs, particularly if this means that truly affordable policies cannot be offered. This threat is particularly heightened in Massachusetts, a state with historically high health care costs. ${ }^{57}$ While not fraudulent or likely even abusive, the potential for failure nonetheless raises the specter of waste on a massive state-wide scale.

\section{Penalties for Misbehavior Under the Massachusetts Plan}

The Massachusetts legislation contains a number of provisions designed to encourage participation in the key aspects of the plan. With regard to the individual and employer mandates, however, the provisions are rather limited, and ultimately unlikely to function as true deterrents to those who would defraud or game the system. It is particularly disheartening to find that many of the commentators who might be expected to object on principle to these mandates, such as authors from the Heritage Foundation, have indicated that they are not opposed to the mandates because they believe the provisions are unlikely to have much of an effect-a trend that likely does not bode well for the potential to achieve the plan's broader goals. ${ }^{58}$

\section{Individuals}

As noted above, as of July 1, 2007, Massachusetts required residents over the age of eighteen to obtain health insurance coverage. ${ }^{59}$ Compliance with this individual mandate is confirmed via the state tax return. Failure to comply - at least when affordable coverage is found to have been available-subjects the individual to a tax penalty. In 2007, the penalty is the loss of the personal tax exemption; in 2008, the penalty will increase to up to $50 \%$ of the cost of the premium of the minimum insurance policy for which the individual would have qualified during

57. See supra note 43 and accompanying text (noting high health care costs in Massachusetts).

58. One Heritage Foundation Web Memo states that employers "can easily avoid the new assessment by signing up to offer coverage to their workers through the Connector. Thus, the provision is likely to have a negligible, or even no, effect." Edmund F. Haislmaier, The Significance of Massachusetts Health Reform, HeRITAGE Found., April 11, 2006, http://www.heritage.org/ Research/HealthCare/wm1035.cfm. With regard to the individual mandate, the same author notes that it "is more onerous and philosophically objectionable, but it is unlikely to prove onerous in practice." Id.

59. An Act Providing Health Care Access, supra note 42, § 12. 
that year. $^{60}$ The penalty is satisfied by first retaining any tax overpayments otherwise due the taxpayer, and then by collecting any balance.

Unfortunately, there are several problems with this enforcement mechanism. First, an individual insurance mandate is highly unlikely to achieve $100 \%$ compliance. We can see this by analogy to the concept of mandated automobile insurance, where even in Massachusetts (a state with fairly high compliance rates) an estimated $7 \%$ of drivers fail to maintain such insurance. ${ }^{61}$ Moreover, while people may exempt themselves from the automobile insurance mandate by choosing not to drive, a comparable option is not available under the health insurance mandate (unless an individual chooses to move out of state). To the extent insurance mandates have not been completely successful in assuring the compliance of even the sub-population of state residents who drive, the assumption that Massachusetts will be able to enforce a mandate applicable to the entire state population is highly questionable. ${ }^{62}$

In addition to the general weaknesses of mandates as a tool to achieve universal health coverage, there are problems with the specific enforcement mechanisms contained in the legislation. Similar to requiring proof of insurance before a car can be registered, using the tax return process to enforce the health insurance mandate is a mechanism designed to permit the state to screen information submitted by a large population of individuals. But there is a significant loophole: this mechanism will not catch individuals who do not file tax returns, a perennial problem even without this additional motivation. To the extent many of the people who do not file tax returns are also those most likely to lack health insurance, such as those with very low incomes, this mechanism may fail to reach the very population that the plan was designed to benefit. ${ }^{63}$

Moreover, for non-risk-averse individuals who could afford to purchase health insurance but prefer not to, taking a "wait and see" approach under the law may be an attractive option. If the individual becomes ill or injured, the mandated open enrollment periods, limited

60. Id.

61. Michael Tanner, The Wrong Road to Reform, HASTINGS CTR. REP., Sept.-Oct. 2006, at 25.

62. Id.

63. See Peter R. Orzag \& Matthew G. Hall, Tax Facts: Nonfilers and Filers with Modest Tax Liabilities, 100 TAX NOTES 723, 723 (2003) (estimating that "almost all" of those who do not file an income tax return have gross incomes of less than $\$ 10,000$ ); Harrington, supra note 39, at 127 (noting the need for heavy penalties to deter the failure of individuals to enroll for services under a mandatory managed competition model, given the importance of identifying the population that must be covered). 
pre-existing condition exclusion and waiting periods, and guaranteed issue requirements may make it easier to purchase insurance when needed. ${ }^{64}$ If the individual does not incur any health care expenses, there is always the possibility that he or she will not be caught by the tax enforcement mechanism. And even if caught, because the maximum penalty after 2008 will be at most $50 \%$ of the cost of the premium for the minimum insurance policy, the individual essentially will end up saving half of the cost of the health plan premium - not a bad deal, in hindsight, if no services were needed.

Finally, even if we discount the potential for individual state residents to make fraudulent or abusive statements regarding their coverage, the affordability loophole remains a significant impediment to achieving the goals of the reform plan. Recall that the requirement of obtaining health care coverage only applies "so long as it is deemed affordable" by the Connector. ${ }^{65}$ As Dr. Marcia Angell has argued, if adequate policies cannot be offered for the relatively low premiums posited by the drafters of the plan, "this will amount to fining people because they can't afford health insurance, which, in effect, will punish them twice." ${ }^{\prime 66}$ As both a practical and a moral matter, affordability may be the exception that swallows the entire reform effort.

\section{Employers}

The situation is similarly bleak on the employer side. Under the payor-play mandate, if an employer with more than ten employees fails to make a fair and reasonable premium contribution to a group health plan, the employer must pay an annual fair share employer contribution of up to $\$ 295$ per employee. ${ }^{67}$ The Director of Labor is instructed to "implement penalties" for noncomplying providers, although no details are set out in the legislation. ${ }^{68}$ In the words of one commentator, this

64. See An Act Relative to Health Care Access, ch. 324, $\S ~ 48,49,2006$ Mass. Acts (forthcoming), available at http://www.mass.gov/legis/laws/seslaw06/s1060324.htm [hereinafter An Act Relative to Health Care Access] (designating limits on waiting and pre-existing condition periods).

65. An Act Providing Health Care Access, supra note 42, $\$ 12$.

66. Angell, supra note 45.

67. MASS. GEN. LAWS ch. 149, § 188(c)(10) (Supp. 2006).

68. Id. $\S 188$ (d). By contrast, the statute spells out specific penalties for employers who fail to timely pay the free rider surcharge when employees who are not offered health insurance use statefunded free care services. MASS. GEN. LAwS ch. 118G, § 18B(e), (h), (i) (Supp. 2006). 
"assessment is in essence a tax on not offering [insurance, or]... additional pressure to offer coverage." 69

It is worth noting that there is some debate as to whether the fair share contribution is properly considered a "penalty" at all. The essence of a pay-or-play provision is to give the employer a choice: provide health insurance to your employees, or pay the required amount into a state fund that will cover their care. In theory, the decision should be value-neutral-under either path, the employees should receive adequately funded health care. Thus, rather than functioning as a penalty for failure to provide health insurance, an employer's payment of the fair share contribution could be characterized as nothing more than a rational choice between equivalent alternatives. ${ }^{70}$

From both a practical and a political perspective, however, it seems difficult to justify this characterization of the Massachusetts law. As a practical matter, there may be little choice to be made at all: given that employers often contribute thousands of dollars toward health insurance premiums for their employees, paying only $\$ 295$ per employee is a very good deal. All things being equal, it seems that most employers would "pay" and very few would "play" under such conditions. Yet if paying is the most rational option for employers, the contribution was not calculated in such a way as to make it equally attractive to the state. Rather than an approximation of the costs of providing insurance to such employees through the Connector, CCHIP subsidies, and expanded MassHealth provisions, the contribution is designed to offset a portion of the costs incurred by the state for care used by the uninsured. ${ }^{71}$ As a result, "this small charge raises less than 5 percent of the total money spent in the legislation, and reflects more than anything a symbolic statement that employers should play some role." ${ }^{, 72}$ While perhaps a rational choice from the employer's perspective, the structure of this provision appears to be an irrational choice by lawmakers with regard to the ultimate fiscal consequences.

69. Gruber, supra note 50 , at 18 .

70. See Elizabeth A. Weeks, Loopholes: Opportunity, Responsibility, or Liability?, 35 J.L. MED. \& ETHICS 320, 323 (2007) (explaining debate).

71. See MASS. GEN. LAWS ch. 149, $\S 188$ (Supp. 2006) (setting forth methodology for calculating contribution). The magnitude of the difference can be seen by comparing this amount to the $\$ 1680$ per worker contribution that would have been required for employers under the pay or play provisions of an earlier Massachusetts reform attempt in 1988 - eighteen years earlier, in a time with significantly lower health care costs. See John E. McDonough et al., The Third Wave of Massachusetts Health Care Access Reform, 2006 HEALTH AFFs.: WEB EXCLUSIVES w420, w420-31 (discussing the 1988 plan and its evolution to the current health plan).

72. Gruber, supra note 50 , at 17. 
The characterization is equally implausible from a political perspective. From even a cursory review of the legislative materials, it is difficult to characterize the fair share contribution as value-neutral in the minds of state legislators. It seems clear that the contribution was viewed by the drafters as a second-best, rather than an equal, alternative to employer-sponsored insurance. The stated goal of the legislation is "to expand access to health care for Massachusetts residents." Quite frankly, it is difficult to see how offering employers the option of paying only a tiny percentage of their workers' health care costs helps to achieve that vision. ${ }^{73}$ Viewed in that light, the $\$ 295$ contribution is, in reality, a political compromise among powerful constituencies with the ability to derail the entire reform effort.

From either perspective, $\$ 295$ is not much of an incentive for an employer to provide health insurance, nor will the payments come close to offsetting the costs of care for the uninsured. The most likely explanation is that the exigencies of the political process served to reduce the fair share contribution to a nearly toothless mechanism to induce employers to offer health insurance to their workers. Even viewed in the alternative, this pay-or-play provision appears to be a gross miscalculation of the state's financial needs. In short, the fair share contribution is simply not fair enough - not enough to sufficiently deter disfavored behaviors, and not enough to provide the revenue otherwise needed to achieve the goals of the legislation.

\section{Broader Fraud and Abuse Safety Net}

Although the anti-fraud provisions in the Massachusetts reform plan are disappointing in light of the additional problems the legislation is likely to invite, the anti-fraud situation is not as bleak as it may first appear. That is because Massachusetts already has in place broad antifraud provisions that will apply to most of the activities undertaken pursuant to the new programs. For example, the state Medicaid statute incorporates strong prohibitions on false statements and representations made in connection with Medicaid benefits (including the failure to disclose material information), as well as a Medicaid-specific equivalent to the federal Anti-Kickback Statute. ${ }^{74}$ While such provisions are fairly standard, Massachusetts has also enacted less-common versions of these

73. An Act Providing Health Care Access, supra note 42, pmbl.; Conversation with Christie Hager, Chief Health Counsel, Office of Speaker Salvatore DiMasi, Massachusetts House of Representatives, on Nov. 10, 2006.

74. MASS. GEN. LAwS ch. 118E, §§ 39-41 (West 2003). 
laws that apply to private health care insurance, including an antikickback provision, a strong prohibition on false statements in health care claims and benefits applications, and a private right of action for an insurer defrauded by health insurance claims containing false statements. $^{75}$ Moreover, the state's civil false claims provisions are closely modeled on the federal False Claims Act, including a private cause of action for qui tam relators. ${ }^{76}$

Massachusetts is not unique in this regard, but it has long been considered one of the most active states in the health care fraud arena. In fact, the Massachusetts false claims provision was the only state law initially found by OIG to meet the terms of the Deficit Reduction Act, under which states are entitled to a favorable percentage of Medicaid fraud recoveries if they have in place a false claims law that is the equivalent of the federal False Claims Act. ${ }^{77}$ Thus, in addition to the unique political, financial, and insurance conditions that made health care reform possible, Massachusetts also has a more favorable anti-fraud environment than many other states-raising further questions about the potential for exporting the Massachusetts approach to other jurisdictions.

\section{CONCLUSION}

What does this analysis mean for similar attempts to achieve universal coverage? To the extent that a market-based approach, combined with moderate expansions in publicly funded health care programs, proves to be the only politically feasible strategy for health care reform at this time, it is likely that both the motivations and the opportunities for people to engage in fraudulent and abusive activities will increase. Experience has shown us that it is far better to plan for these contingencies in advance than to assume, rather naively, that health care reform efforts will mitigate the temptation to take advantage of the system. Or, to put it another way, perhaps even health care reform can't legislate human nature.

75. Id. ch. $175 \mathrm{H}, \S \S 1-3,6$ (West 1998).

76. Id. ch. $12, \S 5 \mathrm{C}$ (West 2002).

77. 42 U.S.C. $\S 1396(\mathrm{~h})(2000)$ (setting forth Deficit Reduction Act requirements); see also Letter from Daniel R. Levinson, Inspector General, to Robert Patten, Assistant Attorney General (Dec. 21, 2006), available at http://www.oig.hhs.gov/fraud/docs/falseclaimsact/Massachusetts.pdf (finding that MASS. GEN. LAwS ch. $12, \S 5$ meets the Deficit Reduction Act requirements). 
*** 